\title{
Performance Assessment of Phase Change Materials Integrated with Building Envelope for Heating Application in Cold Locations
}

\author{
Qudama Al-Yasiri, and Márta Szabó
}

\section{ABSTRACT}

Phase change materials (PCMs) are increasingly investigated in the last years as successful strategy in many thermal energy storage applications. In the building sector, PCMs are utilised to improve building efficiency by reducing cooling/heating loads and promoting renewable energy sources, such as solar energy. This paper shows the recent research works on integrating PCMs with building envelope for heating purposes. The main PCM categories and their main characteristics are presented, focusing on PCM types applied for building heating applications. The main methods adopted to incorporate PCMs with building elements and materials are mentioned, and the popular passive and active incorporation techniques are discussed. Lastly, the main contribution to building energy saving is discussed in terms of heating applications. The analysed studies indicated that all PCMs could improve the building energy saving in the cold climates by up to $44.16 \%$ regardless of their types and incorporation techniques. Several conclusions and recommendations are derived from the analysed studies that are believed to be a guideline for further research.

Keywords: building efficiency, energy saving, passive heating, PCMs

\section{INTRODUCTION}

The building sector plays a key role in the global energy balance as it is the leading responsible sector for a significant share of final energy-use and $\mathrm{CO} 2$ emissions [1]. Besides, building envelope shares the biggest of this ratio as it manages the thermal load between the indoor and door environments and controls the heating and cooling loads [2],[3]. Consequently, the use of efficient and sustainable technologies to increase building energy efficiency are progressively required [4],[5]. In this regard, the incorporation of phase change material (PCM) into building envelope components has been demonstrated to be a promising strategy for building thermal-energy performance improvement in terms of thermal comfort and energy-saving under various locations [6]-[8].
Published Online: February 18, 2021

ISSN: 2736-5506

DOI : 10.24018 /ejenergy.2021.1.1.5

Qudama Al-Yasiri*

Mechanical Engineering Doctoral School, Hungarian University of Agriculture and Life Sciences, Páter K. u. 1, Gödöllö, H-2100, Hungary

Department of Building Services, Institute of Technology, Hungarian University of Agriculture and Life Sciences, Páter K. u. 1, Gödöllö, H-2100, Hungary

Department of Mechanical Engineering, Faculty of Engineering, University of Misan, Al Amarah, Maysan, 62001, Iraq

(e-mail: qudamaalyasiri@uomisan.edu.iq)

Márta Szabó

Department of Building Services, Institute of Technology, Hungarian University of Agriculture and Life Sciences, Páter K. u. 1, Gödöllö, H-2100, Hungary

(e-mail: Szabo.marta@ ${ }^{\circledR}$ szie.hu)

*Corresponding Author
PCMs can store and release a considerable amount of heat as a latent heat during phase transition by around 5-14 times higher than the sensible heat storage materials, per unit volume [9]. They have been introduced as advanced thermal storage materials in many building applications to meet (or support) the thermal load on an annual basis. In general, PCMs are integrated into building envelope materials and elements, such as the roofs [10], walls [11],[12], floors [13], bricks [14], concretes [15], mortars [16], and transparent components [17],[18]. The main benefits of this integration are to save building energy by reducing thermal loads (cooling and heating loads), shaving and shifting peak load to off-load hours [19],[20]. The use of PCMs for heating purposes in buildings has a wide range of applications that can be summarised as presented in Figure 1. 


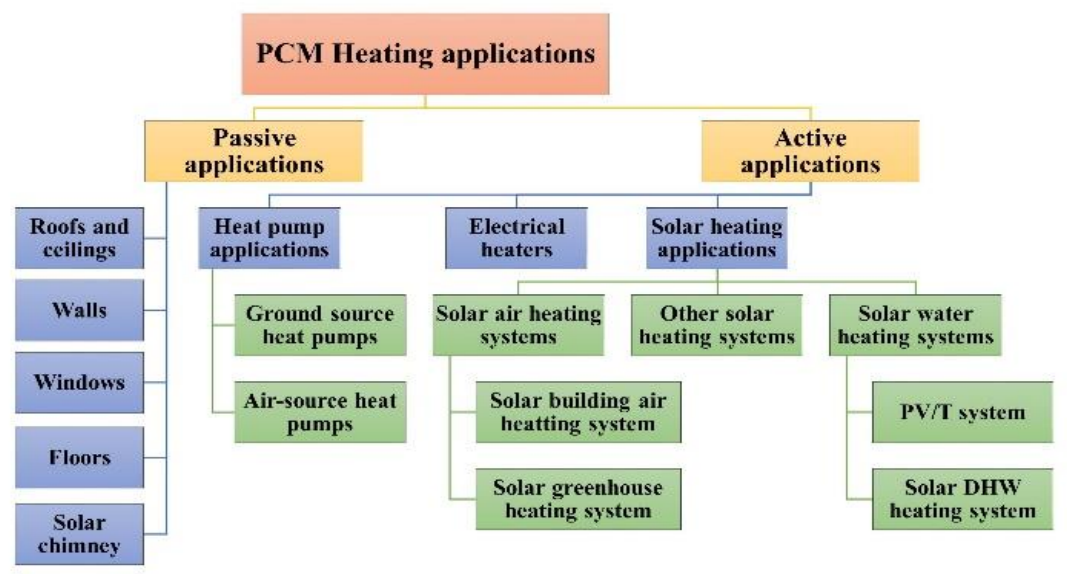

Fig. 1. General applications of PCM for building heating purposes

In this paper, the integration of PCMs into building envelope for heating applications have been discussed. The paper comprises several sections to cover all aspects of PCM heating applications. Section II gives a general overview of PCM categories with their main characteristics and a list of PCM candidates used for building heating applications. Section III deals with the possible methods and incorporation techniques adopted in the literature, whereas section IV discusses PCM's main contributions to the building energy saving. At last, several conclusions raised from the reviewed studies have been presented in section V.

\section{PCM CHARACTERISTICS}

Generally, PCMs are classified into three categories based on their chemical construction: organic, inorganic and eutectics. Organic PCMs are the widely available materials and further classified into paraffinic, and non-paraffinic PCMs such as salt hydrates, fatty acids, esters and glycols [21],[22]. Each category has its advantages and disadvantages resulted from their various characteristics [23]. PCM characteristics are requirements to be considered when studying their utilisation in buildings. These characteristics are mainly related to the PCM melting temperature, heat of fusion, thermal conductivity and density [7].

\section{A. Melting temperature}

Melting temperature is the temperature in which PCM's melting process, and the state change from solid to liquid. Melting temperature is the topmost property of PCM starts, which controls the utilisation of PCM thermal storage capacity. The variation of air-solar temperature should be adequately studied for the location under study to select the proper PCM with suitable melting temperature. For instance, a study carried out under Portugal's climate conditions considered air-solar temperature annually. The study found that the temperature varied between the highest $44{ }^{\circ} \mathrm{C}$ in summer and the lowest $5{ }^{\circ} \mathrm{C}$ in winter period [24]. Therefore, the suggested optimal PCM melting temperatures should be in the range of $10^{\circ} \mathrm{C}$ to $30^{\circ} \mathrm{C}$. In general, each PCM category has a different range of melting temperature, making it suitable for a particular application, as shown in Figure 2.

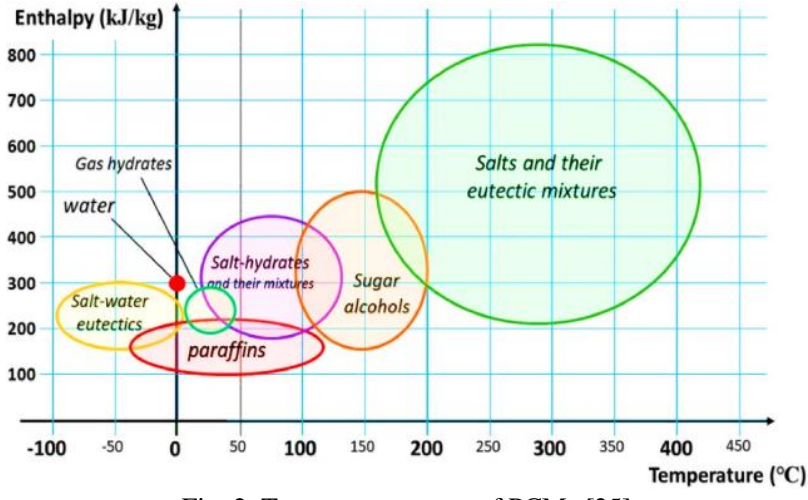

Fig. 2. Temperature range of PCMs [25]

\section{B. Heat of fusion}

The heat of fusion is defined as the quantity of heat required to change $1 \mathrm{~g}$ of solid to liquid under no temperature change (adiabatic process). It sometimes calls as the latent heat of fusion [26], as indicated in Figure 3. In PCM applications, the higher heat of fusion value allows more heat to be stored, making it preferable. The heat of fusion is almost within the range of $120-280 \mathrm{~kJ} / \mathrm{kg}$, regardless of the type of PCM [27].

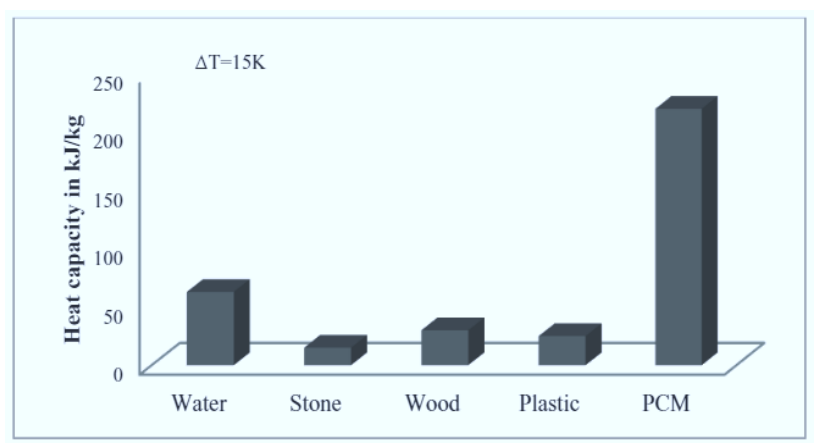

Fig. 3. Heat capacity of PCMs compared with other materials [28]

\section{Thermal conductivity}

Thermal conductivity is the ability of PCM to conduct heat. It is commonly known that all PCMs have low thermal conductivity by nature. Therefore, many enhancement techniques have been applied to improve PCM thermal conductivity such as emersion of nanoparticles, metallic foam, expanded graphite, metal inserts, fins, and macroencapsulation with high thermal conductivity containers [29]-[34]. 


\section{Density}

Density is commonly expressed as the mass of a material to its volume. Together with PCM's thermal conductivity, the density highly influences the rate of heat charging and discharging [35]. It has been reported that the density of organic PCMs ranged from $700 \mathrm{~kg} / \mathrm{m} 3$ to $900 \mathrm{~kg} / \mathrm{m} 3$ and from 1300 to $1800 \mathrm{~kg} / \mathrm{m} 3$ for inorganic PCMs [36].

A list of PCM characteristics for different categories suitable for building applications under hot climate conditions is listed in Table I gathered from the studies reported in the literature.

TABLE I: THERMO-PHYSICAL PROPERTIES OF PCMS

\begin{tabular}{|c|c|c|c|c|c|c|}
\hline PCM type & Category & $\begin{array}{l}\text { Melting temperature } \\
\left({ }^{\circ} \mathrm{C}\right)\end{array}$ & $\begin{array}{l}\text { Heat of fusion } \\
(\mathrm{kJ} / \mathrm{kg})\end{array}$ & $\begin{array}{l}\text { Thermal conductivity } \\
(\mathrm{W} / \mathrm{m} . \mathrm{K})\end{array}$ & Density $\left(\mathrm{kg} / \mathrm{m}^{3}\right)$ & Ref. \\
\hline Paraffin wax & Paraffin & $27-29$ & 245 & 0.2 (Liquid) & $\begin{array}{l}770 \text { (Liquid) } \\
880 \text { (Solid) }\end{array}$ & [37] \\
\hline PureTemp 23 & Paraffin & $22.23-24.17$ & 170.71 & $\begin{array}{c}0.15 \text { (Liquid) } \\
0.25 \text { (Solid) }\end{array}$ & $\begin{array}{c}830 \text { (Liquid) } \\
910 \text { (Solid) }\end{array}$ & {$[38],[39]$} \\
\hline RT-18 & Paraffin & $15-19$ & 134 & 0.2 & 756 & [40] \\
\hline RT27 & Paraffin & 28 & 147 & 0.2 (Liquid) & $\begin{array}{l}750 \text { (Liquid) } \\
870 \text { (Solid) }\end{array}$ & [41] \\
\hline HS29 & Paraffin & $26-29$ & 190 & $\begin{array}{c}0.55 \text { (Liquid) } \\
1.05 \text { (Solid) }\end{array}$ & $\begin{array}{c}1530 \text { (Liquid) } \\
1681 \text { (Solid) }\end{array}$ & {$[42]$} \\
\hline RT-27 & Paraffin & 28 & 179 & 0.2 & $\begin{array}{l}750 \text { (Liquid) } \\
870 \text { (Solid) }\end{array}$ & [43] \\
\hline SP-25 A8 & Hydrated salt & 26 & 180 & 0.6 & 1380 & \\
\hline Hydrated salt & Hydrated salt & 29 & 175 & 1.0 & 1490 & {$[44]$} \\
\hline $\mathrm{CaCl} 2.6 \mathrm{H} 2 \mathrm{O}$ & Hydrated salt & 29.9 & 187 & $\begin{array}{c}0.53 \text { (Liquid) } \\
1.09 \text { (Solid) }\end{array}$ & $\begin{array}{c}1710 \text { (Liquid) } \\
1530 \text { (Solid) }\end{array}$ & {$[45]$} \\
\hline CADE & Fatty acid & 26.5 & 126.9 & $\begin{array}{l}0.2 \text { (Liquid) } \\
0.12 \text { (Solid) }\end{array}$ & $\begin{array}{l}817 \text { (Liquid) } \\
754 \text { (Solid) }\end{array}$ & [46] \\
\hline LA-MA-SA & Fatty acid & 29.05 & 137.1 & N/A & N/A & {$[47]$} \\
\hline CA-MA-PA & Fatty acid & 18.61 & 128.2 & N/A & N/A & {$[48]$} \\
\hline CA-PA & Fatty acid & 26.2 & 177 & 2.2 & 784 & [49] \\
\hline $\mathrm{CA}-\mathrm{PA}-\mathrm{SA}$ & Fatty acid & 19.93 & 129.4 & $\mathrm{~N} / \mathrm{A}$ & N/A & {$[50]$} \\
\hline
\end{tabular}

\section{POSSIBLE INCORPORATION METHODS AND TECHNIQUES}

PCMs can be applied for new and existing buildings during installation or refurbishment stage. They can be incorporated with building envelope directly (by impregnation or direct mixing), or as a separated element (via encapsulation, shape and form stabilised methods) [6]. Furthermore, they can be installed and utilised within the building envelope in a passive or active technique.

In the passive technique, the charging and discharging heat to/from the PCM takes place passively without any external means. Therefore, PCM's thermal performance is influenced by conductive heat flux exchange rate and natural convection currents between the PCM and heat transfer fluid (HTF). In such a case, exchanging heat between the PCM and air (outside and inside environments) is the main key-factor of this technology [51]. Moreover, the passive technique requires high heat transfer surface temperature to accelerate heat charging and discharging time [52]. Possible incorporation methods of PCM with building elements are shown in Figure 4. 


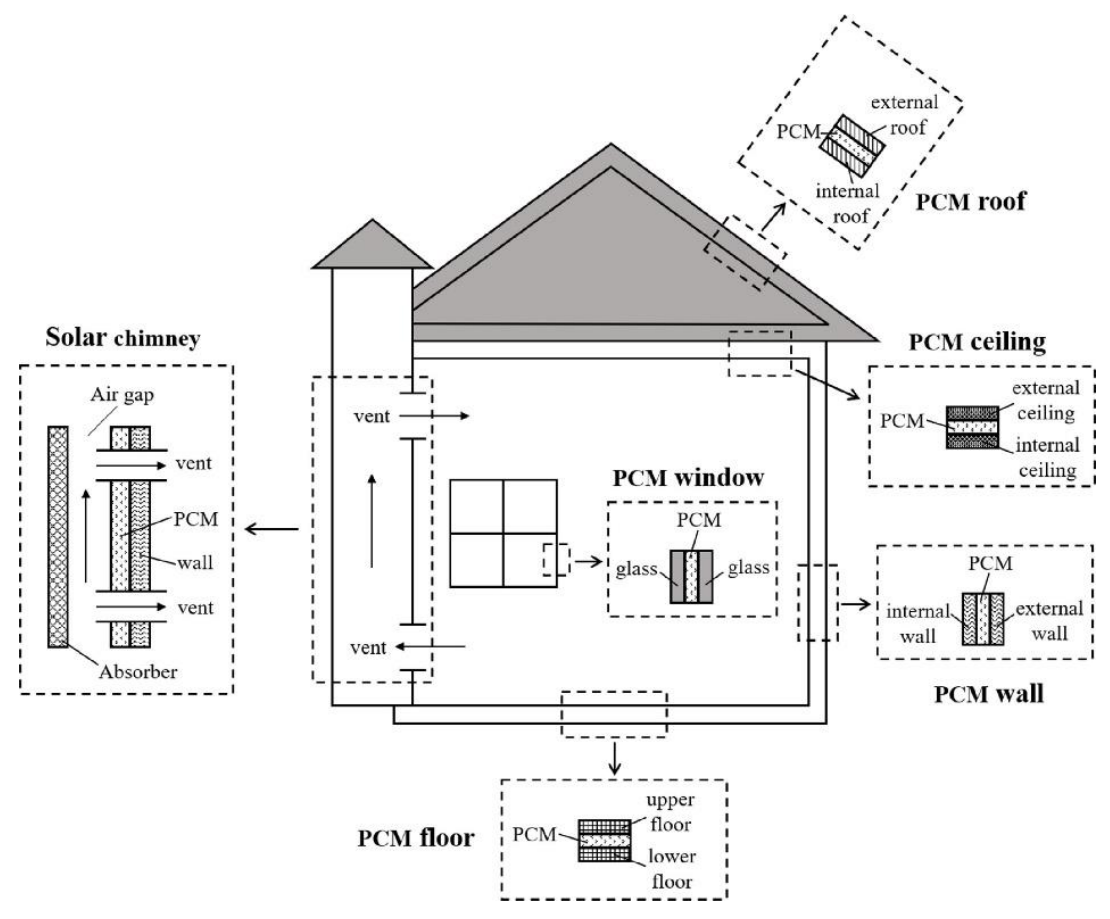

Fig. 4. Passive possibilities to incorporate PCM into building envelope [53]

For active technique, the HTF is forced to charge the heat to the PCM using different means such as solar collectors, blowers and pumps. Hence, the PCM's thermal performance and building element would be enhanced remarkably [54],[55]. The popularly investigated application in this method is utilising solar thermal energy to charge heat via solar collectors where air or water work as an HTF. For instance, when the water applied as an HTF, the heat harvested by solar collectors is transferred to the water and then, charged into the PCM integrated with the building envelope, as shown in Figure 5.

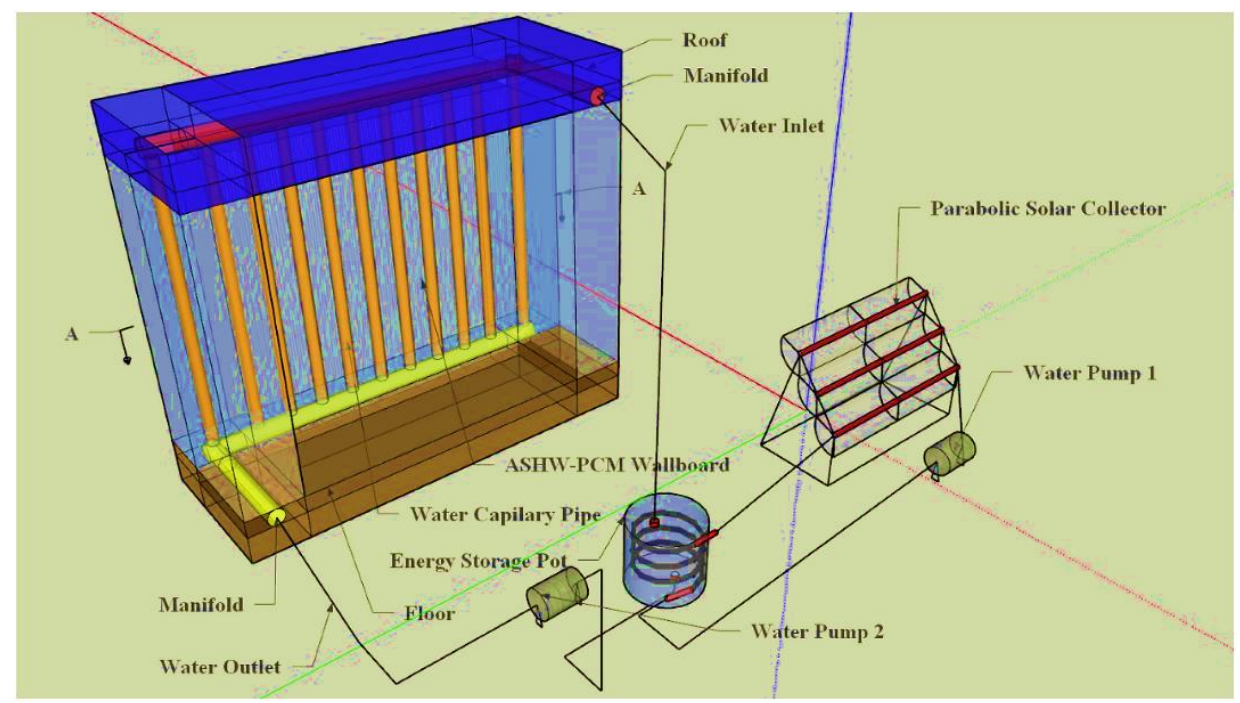

Fig. 5. Active solar water system coupled building envelope PCM [56]

In general, PCM's applicability into the building envelope, passively or actively, depends highly on PCM's melting temperature and the daily range of temperatures during the day and night to ensure full melting/solidification of PCM [13]. The possible passive and active methods reported in the literature are represented in Figure 6. 


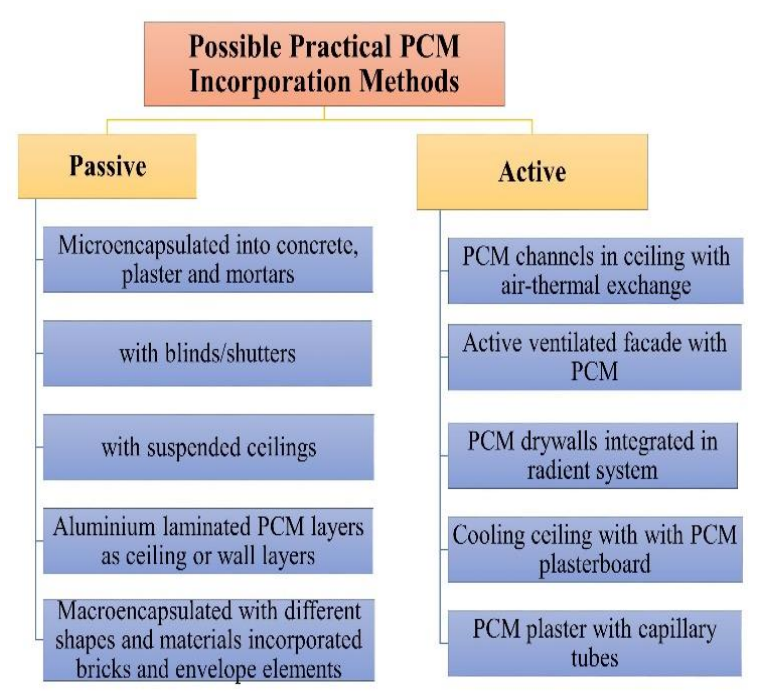

Fig. 6. Possible incorporation methods of PCM into building envelope [57]

\section{CONTRIBUTION OF PCM TO THE BUILDING ENERGY}

For heating purposes under cold locations, PCMs mainly utilised in two ways: absorb the heat during day hours and release it during low-temperature nights. Secondly, restrict the heat escaping from the hot interior environment towards the exterior environment due to temperature difference. PCMs can absorb the heat resulting from relative high diurnal solar energy during day hours and release it during night hours due to temperature difference. Therefore, they can be applied as a heat supplier when it incorporates building envelope under cold climate conditions [58]. It has been reported that PCMs can increase the thermal storage of the building envelope, which is usually constructed from materials with low thermal inertia [59]. Seong and Lim [60] numerically studied the thermal benefits of PCMs have different melting temperatures incorporated lightweight building envelope under weather conditions of Seol, Korea. Considering the contribution to the heating application, PCM of $21^{\circ} \mathrm{C}$ melting temperature performed the best in heating load reduction and indoor temperature increase on an annual basis. Results showed that PCM could improve the building efficiency in which the peak heating load was reduced by
$3.19 \%$ and the indoor temperature increased by $0.86{ }^{\circ} \mathrm{C}$. Araújo et al. [61] studied the potential of eight PCMs with different melting temperatures (RT 15, RT 18, RT 21, RT 22, RT 24, RT 25, RT 26 and RT 28) for residential building located in northern Portugal. Numerical results obtained by EnergyPluse dynamic tool indicated that the RT 22 showed the best performance in which the heating needs were reduced by $8.22 \mathrm{kWh} / \mathrm{m}^{2} /$ year, representing heating energy saving of $13.2 \%$. $\mathrm{Hu}$ and $\mathrm{Yu}$ [62] numerically studied the thermal response of building integrated with $\mathrm{PCM}\left(21.7^{\circ} \mathrm{C}\right.$ melting temperature) under Chinese cities' diverse climate conditions. Considering the cold conditions of Nanjing, the maximum monthly heating loads reduction of $0.8 \mathrm{kWh} / \mathrm{m}^{2}$ in November, $\quad 2.2 \mathrm{kWh} / \mathrm{m}^{2}$ in December, $1.4 \mathrm{kWh} / \mathrm{m}^{2}$ in January, $1.9 \mathrm{kWh} / \mathrm{m}^{2}$ and $1.2 \mathrm{kWh} / \mathrm{m}^{2}$ in March which represent energy saving by $14 \%, 10 \%, 4 \%, 9 \%$ and $13 \%$ respectively. The study concluded that the maximum energy saving obtained in the coldest months in the year emphasises the applicability of PCMs. Guarino et al. [63] numerically and experimentally tested PCM wallboard $\left(18-24{ }^{\circ} \mathrm{C}\right.$ melting temperature) combined the south-oriented interior surface wall opposing a highly glazed façade under cold climate conditions of Montreal, Canada. The study aimed to increase the wall's thermal performance by storing the heat passes through the glazed façade to be released later. Results showed that the solar radiation was stored during day hours and released for 6-8 $\mathrm{h}$ after sunset which reduced the daily temperature swings (up to $10^{\circ} \mathrm{C}$ ) and heating requirements (more than $17 \%$, yearly). Kong et al. [64] invented a hybrid system by coupling perlite-based composite PCM wallboard with a solar heating system. The hybrid system was placed to the inside of the tested room's wall and compared with another reference room without PCM (woring with heating radiators) for three working days under winter conditions of Tianjin, China. The analysed results showed that the daily heating energy consumption was reduced by $44.16 \%$ in the room provided with hybrid system compard with the other room without PCM. Moreover, the study concluded that such system could maintain the required comfort environment and enhance buildings' efficiency. A detailed summary of some similar studies is listed in Table II.

TABLE II: SUMMARY OF LITERATURE STUDIES DEALING WITH THE CONTRIBUTION OF PCM FOR BUILDING HEATING APPLICATIONS

\begin{tabular}{|c|c|c|c|c|c|c|}
\hline $\begin{array}{l}\text { PCM type (melting } \\
\left.\text { temperature, }{ }^{\circ} \mathrm{C}\right)\end{array}$ & $\begin{array}{c}\text { Location } \\
\text { Country (city) } \\
\end{array}$ & $\begin{array}{l}\text { Building } \\
\text { element }\end{array}$ & $\begin{array}{c}\text { Incorporation } \\
\text { technique }\end{array}$ & Study type & Contribution to the energy-saving (ES) & Ref. \\
\hline $\begin{array}{l}\text { PCM24D (21.9) } \\
\text { RT21 (21) }\end{array}$ & $\begin{array}{l}\text { Norway } \\
\text { (Oslo) }\end{array}$ & Walls & Passive & Numerical & $\begin{array}{l}\text { Energy reduction of } 23 \% \text { was obtained during } \\
\text { the winter. }\end{array}$ & {$[65]$} \\
\hline $\begin{array}{c}\text { BioPCM- Q25/M91 } \\
\text { (25) }\end{array}$ & $\begin{array}{l}\text { Greece } \\
\text { (Athens) }\end{array}$ & Walls & Passive & Numerical & The heating loads reduced by $1.54 \%$ & [66] \\
\hline GH-20 (20-25.4) & $\begin{array}{c}\text { China } \\
\text { (Shanghai) }\end{array}$ & Wall & Passive & $\begin{array}{l}\text { Numerical }+ \\
\text { Experimental }\end{array}$ & $\begin{array}{l}\text { The heating load reduced by } 10-30 \% \text {, and } 9- \\
72 \% \text { reduction of the heat lost from the interior } \\
\text { wall surface was reached. }\end{array}$ & [67] \\
\hline $\begin{array}{c}\text { n-Octadecane } \\
(18.80-37.83) \\
\text { Beeswax (33.41- } \\
61.05)\end{array}$ & $\begin{array}{l}\text { United States } \\
\text { (Miami and } \\
\text { others) }\end{array}$ & Walls & Passive & Numerical & $\begin{array}{l}\text { In Miami, ES of } 7.8 \% \text { and } 6.4 \% \text { achieved when } \\
n \text {-Octadecane and Beeswax applied during the } \\
\text { heating season. }\end{array}$ & [68] \\
\hline RT-21 (21-22) & Spain & Slab & $\begin{array}{l}\text { Active (solar } \\
\text { air collector) }\end{array}$ & Experimental & $\begin{array}{l}\text { energy-saving of } 25 \% \text { and } 40 \% \text { during the severe } \\
\text { and mild winter conditions, respectively }\end{array}$ & [69] \\
\hline $\begin{array}{l}\text { Composite PCM: } \\
\text { SP } 29(28-30) \& \\
\text { RT } 18(17-19)\end{array}$ & $\begin{array}{c}\text { China } \\
\text { (Shanghai) }\end{array}$ & $\begin{array}{l}\text { Walls }+ \\
\text { roof }\end{array}$ & Passive & $\begin{array}{l}\text { Numerical }+ \\
\text { Experimental }\end{array}$ & $\begin{array}{l}\text { During the nighttime, the temperature raised by } \\
6.93-9.48{ }^{\circ} \mathrm{C} \text { for PCM room and the indoor air } \\
\text { temperature fluctuation decreased by } 17.7-25.4 \% \\
\text { during the sunny time. In conclusion, the PCM } \\
\text { has increased the heat released to the room and } \\
\text { decreased the heat escaped from the room. }\end{array}$ & [70] \\
\hline
\end{tabular}




\section{CONCLUSION}

PCMs are among booming technologies nowadays thanks to their remarkable potential as thermal energy storage in different applications. In building applications, it has been proven that PCMs can effectively improve the energy efficiency and maintain acceptable thermal comfort on an annual basis. The current paper discusses the potential of PCMs to improve the heating energy saving when incorporated building envelope under cold locations. In this regard, the following conclusions are derived from the analysed studies:

1) Generally, the melting temperature of PCMs used for building heating applications ranged between $15^{\circ} \mathrm{C}-$ $30{ }^{\circ} \mathrm{C}$ regardless of the type of PCM.

2) Most of studied PCM types were organic (Paraffins, fatty acids and hydrated salts) as they have a suitable melting temperature for building applications. Besides, there is no eutectics were studied in such applications due to their high melting temperatures which are not suitable for such application.

3) Most of studies discussed the incorporation of PCMs for building thermal applications were investigated passively. Besides, very limited ones considered the active technique using solar thermal and other renewable systems due to the complexity of coupling PCM with active systems.

4) Solar thermal systems integrated PCMs for building heat application has a significant role to increase the benefits of utilizing solar energy and building efficiency. However, emerge other heat sources with PCMs is still out of scope which can be a novel heat recovery systems.

5) Number of numerical studies are much higher than the experimental studies mainly due to a variety of simulation tools and complexity of incorporation techniques, especially the active ones.

6) The main thermal contribution to energy saving reported in the literature for PCMs applied under cold climates was presented in terms of decreasing the heating loads and maintaining a suitable thermal comfort throughout the year.

7) Energy saving by up to $44.16 \%$ can be obtained from integrating PCMs with building envelope which represents a huge contribution for building energysaving by PCM technology.

\section{ACKNOWLEDGMENT}

This work was supported by the Stipendium Hungaricum Scholarship Programme and the Mechanical Engineering Doctoral School, Hungarian University of Agriculture and Life Sciences, Gödöllő, Hungary.

\section{REFERENCES}

[1] International Energy Agency (IEA), “Technology Roadmap. Energy efficent building envelopes," $2013 . \quad$ doi: 10.1007/SpringerReference_7300.

[2] E. Lambie and D. Saelens, "Identification of the building envelope performance of a residential building: A case study," Energies, vol. 13, no. 10, pp. 1-28, 2020, doi: 10.3390/en13102469.

[3] Q. Al-Yasiri, M. A. Al- Furaiji, and A. K. Alshara, "Comparative study of building envelope cooling loads in Al-Amarah city, Iraq," J. Eng. Technol. Sci., vol. 51, no. 5, pp. 632-648, 2019, doi: 10.5614/j.eng.technol.sci.2019.51.5.3.
[4] DOE-USA, "An Assessment of Energy Technologies and Research Opportunities," Chapter 5 Increasing Effic. Build. Syst. Technol., no. September, pp. 143-181, 2015, [Online]. Available: https://www.energy.gov/sites/prod/files/2017/03/f34/qtr-2015chapter5.pdf.

[5] F. Darvishi, E. Markarian, N. Ziasistani, N. Ziasistani, and A Javanshir, "Energy performance assessment of PCM buildings considering multiple factors," 5th Int. Conf. Power Gener. Syst. Renew. Energy Technol. PGSRET 2019, pp. 1-5, 2019, doi: 10.1109/PGSRET.2019.8882672.

[6] Q. Al-Yasiri and M. Szabó, "Incorporation of phase change materials into building envelope for thermal comfort and energy saving: A comprehensive analysis,” J. Build. Eng., vol. 36, p. 102122, 2021, doi: https://doi.org/10.1016/j.jobe.2020.102122.

[7] A. Madad, T. Mouhib, and A. Mouhsen, "Phase change materials for building applications: A thorough review and new perspectives," Buildings, vol. 8, no. 5, 2018, doi: 10.3390/buildings8040063.

[8] C. Piselli, M. Prabhakar, A. de Gracia, M. Saffari, A. L. Pisello, and L. F. Cabeza, "Optimal control of natural ventilation as passive cooling strategy for improving the energy performance of building envelope with PCM integration," Renew. Energy, vol. 162, 2020, doi: 10.1016/j.renene.2020.07.043.

[9] J. Z. Alvi, Y. Feng, Q. Wang, M. Imran, L. A. Khan, and G. Pei, "Effect of Phase Change Material Storage on the Dynamic Performance of a Direct Vapor Generation Solar Organic Rankine Cycle System," Energies, vol. 13, no. 22, p. 5904, 2020, doi: 10.3390/en13225904.

[10] J. Gong, M. Zheng, Z. Yu, and X. Liu, "Adjustable insulation for enhancing the performance of phase change materials in buildings," Int. J. Energy Res., vol. 44, no. 5, 2020, doi: 10.1002/er.5149.

[11] E. Tunçbilek, M. Arıcı, M. Krajčík, S. Nižetić, and H. Karabay, "Thermal performance based optimization of an office wall containing PCM under intermittent cooling operation," Appl. Therm. Eng., vol. 179, no. October 2020, p. 115750, 2020, doi: 10.1016/j.applthermaleng.2020.115750.

[12] M. Arıc1, F. Bilgin, S. Nižetić, and H. Karabay, "PCM integrated to external building walls: An optimization study on maximum activation of latent heat," Appl. Therm. Eng., vol. 165, no. January 2020, p. 114560, 2020, doi: 10.1016/j.applthermaleng.2019.114560.

[13] N. Zhu, S. Li, P. Hu, S. Wei, R. Deng, and F. Lei, "A review on applications of shape-stabilized phase change materials embedded in building enclosure in recent ten years," Sustain. Cities Soc., vol. 43, pp. 251-264, 2018, doi: 10.1016/j.scs.2018.08.028.

[14] M. Mahdaoui et al., "Building bricks with phase change material (PCM): Thermal performances," Constr. Build. Mater., vol. 269, no.

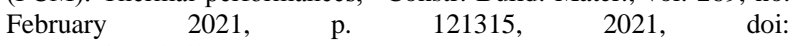
10.1016/j.conbuildmat.2020.121315.

[15] H.-D. Do Yun, K.-L. L. Ahn, S.-J. J. Jang, B.-S. S. Khil, W.-S. S. Park, and S.-W. W. Kim, "Thermal and Mechanical Behaviors of Concrete with Incorporation of Strontium-Based Phase Change Material (PCM)," Int. J. Concr. Struct. Mater., vol. 13, no. 1, p. 18, 2019, doi: 10.1186/s40069-018-0326-8.

[16] P. Sukontasukkul, T. Sutthiphasilp, W. Chalodhorn, and P. Chindaprasirt, "Improving thermal properties of exterior plastering mortars with phase change materials with different melting temperatures: paraffin and polyethylene glycol," Adv. Build. Energy Res., vol. 13, no. 2, pp. 220-240, Jul. 2019, doi: 10.1080/17512549.2018.1488614.

[17] I. Vigna, L. Bianco, F. Goia, and V. Serra, "Phase change materials in transparent building envelopes: A Strengths, Weakness, Opportunities and Threats (SWOT) analysis," Energies, vol. 11, no. 1, 2018, doi: 10.3390/en11010111.

[18] D. Li, Y. Wu, C. Liu, G. Zhang, and M. Arıcı, "Energy investigation of glazed windows containing Nano-PCM in different seasons," Energy Convers. Manag., vol. 172, no. April, pp. 119-128, 2018, doi: 10.1016/j.enconman.2018.07.015.

[19] E. Tunçbilek, M. Arıcı, S. Bouadila, and S. Wonorahardjo, "Seasonal and annual performance analysis of PCM-integrated building brick under the climatic conditions of Marmara region," J. Therm. Anal Calorim., vol. 141, no. 0123456789, pp. 613-624, 2020, doi: 10.1007/s10973-020-09320-8.

[20] P. K. S. Rathore, S. K. Shukla, and N. K. Gupta, "Yearly analysis of peak temperature, thermal amplitude, time lag and decrement factor of a building envelope in tropical climate," J. Build. Eng., vol. 31, no. April, p. 101459, 2020, doi: 10.1016/j.jobe.2020.101459.

[21] R. Zeinelabdein, S. Omer, and G. Gan, "Critical review of latent heat storage systems for free cooling in buildings," Renew. Sustain. Energy Rev., vol. 82, no. October 2017, pp. 2843-2868, 2018, doi: 10.1016/j.rser.2017.10.046.

[22] K. Faraj, M. Khaled, J. Faraj, F. Hachem, and C. Castelain, "Phase change material thermal energy storage systems for cooling 
applications in buildings: A review," Renew. Sustain. Energy Rev., vol. 119, no. December 2018, p. 109579, 2020, doi: 10.1016/j.rser.2019.109579.

[23] S. S. Chandel and T. Agarwal, "Review of current state of research on energy storage, toxicity, health hazards and commercialization of phase changing materials," Renew. Sustain. Energy Rev., vol. 67, pp. 581596, 2017, doi: 10.1016/j.rser.2016.09.070.

[24] M. Kheradmand, M. Azenha, J. L. B. de Aguiar, and J. Castro-Gomes, "Experimental and numerical studies of hybrid PCM embedded in plastering mortar for enhanced thermal behaviour of buildings,' Energy, vol. 94, pp. 250-261, 2016, doi: 10.1016/j.energy.2015.10.131.

[25] R. Baetens, B. P. Jelle, and A. Gustavsen, "Phase change materials for building applications: A state-of-the-art review," Energy Build., vol. 42, no. 9, pp. 1361-1368, 2010, doi: 10.1016/j.enbuild.2010.03.026.

[26] M. B. Kirkham, "Chapter 3 - Structure and Properties of Water," in Principles of Soil and Plant Water Relations (Second Edition), Second Edi., M. B. Kirkham, Ed. Boston: Academic Press, 2014, pp. 27-40.

[27] S. L. Bardage, "6 - Performance of buildings," in Performance of Biobased Building Materials, D. Jones and C. Brischke, Eds. Woodhead Publishing, 2017, pp. 335-383.

[28] L. Kancane, R. Vanaga, and A. Blumberga, "Modeling of Building Envelope's Thermal Properties by Applying Phase Change Materials,' Energy Procedia, vol. 95, pp. 175-180, 2016, doi: https://doi.org/10.1016/j.egypro.2016.09.041.

[29] C. Amaral, R. Vicente, P. A. A. P. Marques, and A. Barros-Timmons, "Phase change materials and carbon nanostructures for thermal energy storage: A literature review," Renew. Sustain. Energy Rev., vol. 79, no. May, pp. 1212-1228, 2017, doi: 10.1016/j.rser.2017.05.093.

[30] Z. A. Qureshi, H. M. Ali, and S. Khushnood, "Recent advances on thermal conductivity enhancement of phase change materials for energy storage system: A review," Int. J. Heat Mass Transf., vol. 127, pp. 838-856, 2018, doi: 10.1016/j.ijheatmasstransfer.2018.08.049.

[31] B. Shang, J. Hu, R. Hu, J. Cheng, and X. Luo, "Modularized thermal storage unit of metal foam/paraffin composite," Int. J. Heat Mass Transf., vol. 125, pp. 596-603, 2018.

[32] S. Nižetić, M. Jurčević, M. Arıcı, A. V. Arasu, and G. Xie, "Nanoenhanced phase change materials and fluids in energy applications: A review," Renew. Sustain. Energy Rev., vol. 129, p. 109931, 2020.

[33] Q. Al-Yasiri and M. Szabó, "Influential aspects on melting and solidification of PCM energy storage containers in building envelope applications," Int. J. Green Energy, 2021, doi https://doi.org/10.1080/15435075.2021.1890082.

[34] S. A. Shehzad, B. Alshuraiaan, M. S. Kamel, M. Izadi, and T. Ambreen, "Influence of fin orientation on the natural convection of aqueousbased nano-encapsulated PCMs in a heat exchanger equipped with wing-like fins," Chem. Eng. Process. - Process Intensif., p. 108287, 2020, doi: https://doi.org/10.1016/j.cep.2020.108287.

[35] B. Peng et al., "Effects of thermal conductivity and density on phase change materials-based thermal energy storage systems," Energy, vol. 172, pp. 580-591, 2019, doi: 10.1016/j.energy.2019.01.147.

[36] Y. Cui, J. Xie, J. Liu, J. Wang, and S. Chen, “A review on phase change material application in building," Adv. Mech. Eng., vol. 9, no. 6, pp. 1-15, 2017, doi: 10.1177/1687814017700828.

[37] X. Sun et al., "Use of encapsulated phase change materials in lightweight building walls for annual thermal regulation," Energy, vol. 180, pp. 858-872, 2019, doi: 10.1016/j.energy.2019.05.112.

[38] L. Navarro et al., "Benchmarking of useful phase change materials for a building application,” Energy Build., vol. 182, pp. 45-50, 2019, doi: 10.1016/j.enbuild.2018.10.005.

[39] PureTemp Company, "PureTemp ${ }^{\circledR}$ Thermal Energy Storage Materials PureTemp 48 Technical Information," 2020. [Online]. Available: https://www.puretemp.com/stories/puretemp-23-tds.

[40] R. Vicente and T. Silva, "Brick masonry walls with PCM macrocapsules: An experimental approach," Appl. Therm. Eng., vol. 67, no. 1-2, pp. 24-34, 2014, doi: 10.1016/j.applthermaleng.2014.02.069.

[41] X. Sun, M. A. Medina, K. O. Lee, and X. Jin, "Laboratory assessment of residential building walls containing pipe-encapsulated phase change materials for thermal management," Energy, vol. 163, pp. 383 391, 2018, doi: 10.1016/j.energy.2018.08.159.

[42] S. Kumar, S. Arun Prakash, V. Pandiyarajan, N. B. Geetha, V. Antony Aroul Raj, and R. Velraj, "Effect of phase change material integration in clay hollow brick composite in building envelope for thermal management of energy efficient buildings," J. Build. Phys., vol. 43, no. 4, pp. 351-364, 2019, doi: 10.1177/1744259119867462.

[43] A. Castell, I. Martorell, M. Medrano, G. Pérez, and L. F. Cabeza "Experimental study of using PCM in brick constructive solutions for passive cooling," Energy Build., vol. 42, no. 4, pp. 534-540, 2010, doi: 10.1016/j.enbuild.2009.10.022.
[44] A. C. Evers, M. A. Medina, and Y. Fang, "Evaluation of the thermal performance of frame walls enhanced with paraffin and hydrated salt phase change materials using a dynamic wall simulator," Build. Environ., vol. 45, no. 8, pp. 1762-1768, 2010, doi https://doi.org/10.1016/j.buildenv.2010.02.002.

[45] N. Hichem, S. Noureddine, S. Nadia, and D. Djamila, "Experimental and numerical study of a usual brick filled with PCM to improve the thermal inertia of buildings," Energy Procedia, vol. 36, pp. 766-775, 2013, doi: https://doi.org/10.1016/j.egypro.2013.07.089.

[46] X. Kong, S. Lu, J. Huang, Z. Cai, and S. Wei, "Experimental research on the use of phase change materials in perforated brick rooms for cooling storage," Energy Build., vol. 62, pp. 597-604, 2013, doi: https://doi.org/10.1016/j.enbuild.2013.03.048.

[47] C. Liu, Y. Yuan, N. Zhang, X. Cao, and X. Yang, "A novel PCM of lauric-myristic-stearic acid/expanded graphite composite for thermal energy storage," Mater. Lett., vol. 120, pp. 43-46, 2014, doi: https://doi.org/10.1016/j.matlet.2014.01.051.

[48] Y. Yuan, Y. Yuan, N. Zhang, Y. Du, and X. Cao, "Preparation and thermal characterization of capric-myristic-palmitic acid/expanded graphite composite as phase change material for energy storage," Mater. Lett., vol. 125, pp. 154-157, 2014, doi https://doi.org/10.1016/j.matlet.2014.04.002.

[49] M. Sayyar, R. R. Weerasiri, P. Soroushian, and J. Lu, "Experimental and numerical study of shape-stable phase-change nanocomposite toward energy-efficient building constructions," Energy Build., vol. 75, pp. 249-255, 2014, https://doi.org/10.1016/j.enbuild.2014.02.018.

[50] Y. Yuan, T. Li, N. Zhang, X. Cao, and X. Yang, "Investigation on thermal properties of capric-palmitic-stearic acid/activated carbon composite phase change materials for high-temperature cooling application,” J. Therm. Anal. Calorim., vol. 124, no. 2, pp. 881-888, 2016, doi: 10.1007/s10973-015-5173-0.

[51] M. Iten, S. Liu, and A. Shukla, "A review on the air-PCM-TES application for free cooling and heating in the buildings," Renew. Sustain. Energy Rev., vol. 61, pp. 175-186, 2016, doi: 10.1016/j.rser.2016.03.007.

[52] V. A. A. Raj and R. Velraj, "Review on free cooling of buildings using phase change materials," Renew. Sustain. Energy Rev., vol. 14, no. 9 , pp. 2819-2829, 2010, doi: 10.1016/j.rser.2010.07.004.

[53] Y. Li, N. Nord, Q. Xiao, and T. Tereshchenko, "Building heating applications with phase change material: A comprehensive review," J. Energy Storage, vol. 31, p. 101634, 2020, doi: 10.1016/j.est.2020.101634.

[54] X. Chen, Q. Zhang, Z. J. Zhai, and X. Ma, "Potential of ventilation systems with thermal energy storage using PCMs applied to air conditioned buildings," Renew. Energy, vol. 138, pp. 39-53, 2019, doi: 10.1016/j.renene.2019.01.026

[55] S. Lu et al., "A Review of PCM Energy Storage Technology Used in Buildings for the Global Warming Solution," in Energy Solutions to Combat Global Warming, X. Zhang and I. Dincer, Eds. Cham: Springer International Publishing, 2017, pp. 611-644.

[56] X. Qiao, X. Kong, H. Li, L. Wang, and H. Long, "Performance and optimization of a novel active solar heating wall coupled with phase change material," J. Clean. Prod., vol. 250, p. 119470, 2020, doi: 10.1016/j.jclepro.2019.119470

[57] F. Souayfane, F. Fardoun, and P. H. Biwole, "Phase change materials (PCM) for cooling applications in buildings: A review," Energy Build., vol. 129, pp. 396-431, 2016, doi: 10.1016/j.enbuild.2016.04.006.

[58] A. de Gracia, "Dynamic building envelope with PCM for cooling purposes - Proof of concept," Appl. Energy, vol. 235, no. November 2018, pp. 1245-1253, 2019, doi: 10.1016/j.apenergy.2018.11.061.

[59] A. Kushwah, M. Kumar Gaur, and R. Kumar Pandit, "The Role of Phase Change Materials for Lifetime Heating of Buildings in Cold Climatic Conditions," Int. J. Built Environ. Sustain., vol. 7, no. 3, pp. 81-96, 2020, doi: 10.11113/ijbes.v7.n3.600.

[60] Y. B. Seong and J. H. Lim, "Energy saving potentials of phase change materials applied to lightweight building envelopes," Energies, vol. 6 , no. 10 , pp. 5219-5230, 2013, doi: 10.3390/en6105219.

[61] C. Araújo, A. Pinheiro, and L. Bragança, "Phase Change Materials as a solution to improve energy efficiency in Portuguese residential buildings," in IOP Conference Series: Materials Science and Engineering, 2017, vol. 251, no. 1, p. 12110, doi: 10.1088/1757 899X/251/1/012110.

[62] J. Hu and X. Yu, "Thermo and light-responsive building envelope: Energy analysis under different climate conditions," Sol. Energy, vol. 193, no. August, pp. 866-877, 2019, doi: 10.1016/j.solener.2019.10.021.

[63] F. Guarino, A. Athienitis, M. Cellura, and D. Bastien, "PCM thermal storage design in buildings: Experimental studies and applications to 
solaria in cold climates," Appl. Energy, vol. 185, pp. 95-106, 2017 doi: 10.1016/j.apenergy.2016.10.046.

[64] X. Kong, L. Wang, H. Li, G. Yuan, and C. Yao, "Experimental study on a novel hybrid system of active composite PCM wall and solar thermal system for clean heating supply in winter," Sol. Energy, vol. 195, no. February 2019, pp. 259-270, 2020, doi: 10.1016/j.solener.2019.11.081.

[65] V. D. Cao, T. Q. Bui, and A. L. Kjøniksen, "Thermal analysis of multilayer walls containing geopolymer concrete and phase change materials for building applications," Energy, vol. 186, p. 115792, 2019, doi: 10.1016/j.energy.2019.07.122

[66] M. T. Plytaria, C. Tzivanidis, E. Bellos, I. Alexopoulos, and K. A. Antonopoulos, "Thermal behavior of a building with incorporated phase change materials in the South and the North Wall," Computation, vol. 7, no. 1, 2019, doi: 10.3390/computation7010002.

[67] X. Wang, H. Yu, L. Li, and M. Zhao, "Experimental assessment on the use of phase change materials (PCMs)-bricks in the exterior wall of a full-scale room,” Energy Convers. Manag., vol. 120, pp. 81-89, 2016, doi: 10.1016/j.enconman.2016.04.065.

[68] S. G. Jeong, S. Wi, S. J. Chang, J. Lee, and S. Kim, “An experimental study on applying organic PCMs to gypsum-cement board for improving thermal performance of buildings in different climates," Energy Build., vol. 190, pp. 183-194, 2019, doi: 10.1016/j.enbuild.2019.02.037.

[69] L. Navarro, A. de Gracia, A. Castell, and L. F. Cabeza, "Experimental study of an active slab with PCM coupled to a solar air collector for heating purposes," Energy Build., vol. 128, pp. 12-21, 2016, doi: 10.1016/j.enbuild.2016.06.069.

[70] E. Meng, H. Yu, and B. Zhou, "Study of the thermal behavior of the composite phase change material (PCM) room in summer and winter,' Appl. Therm. Eng., vol. 126, pp. 212-225, 2017, doi: 10.1016/j.applthermaleng.2017.07.110. 